\title{
An Analysis of Integrated Practicum Demands of Virtual Lab Models in Hydrocarbon Materials
}

\author{
Erlina \\ Chemistry Education, Faculty of Mathematics and Natural Sciences, Medan State University, Indonesia \\ email: Erlinasayna@gmail.com
}

\begin{abstract}
This study aims to determine the effect of the implementation of a practical guide to interact with a virtual laboratory model on students' understanding of practicing on hydrocarbon materials. Students' understanding is included in the dimensions of cognitive and affective processes. This research was conducted at the Percut Sei Tuan Pure Pure Private High School in the odd semester of the 2018/2019 school year. The research method used was quasi experimental design with pretest-posttest control group design. Sampling was done using purposive sampling technique. The sample in the study were students of class XI MIA 2 as an experimental group with learning using virtual laboratories and students of class XI MIA 1 as a control group using conventional learning. The sample in each group amounted to 36 people. Data retrieval is done using a description of students' concept understanding. Data analysis using independent sample T-Test test obtained $t$ count of 3.021 with $t$ table 2.045 means that $t$ count $>t$ table and significant value $0.004<0.05$. Then Ho is rejected and $\mathrm{HI}$ is accepted at a significant level of 0.05 so it is concluded that there is a significant difference between the average posttest value of the experimental group and the control group. This shows that there is an effect of applying virtual laboratories to students' concept understanding.
\end{abstract}

Keywords: practical guide; virtual laboratory; hydrocarbons

\section{Introduction}

Natural Science is closely related to practicum conducted in the laboratory. As a means of supporting learning activities, the existence of laboratories in schools is very important because there are laboratory equipment and other supporting infrastructure. In reality, not all schools have a laboratory and if they have a laboratory, most schools do not have complete infrastructure to conduct the desired practicum activities. As a substitute for practicum activities in real rium laboratories, virtual labs can be used. Virtual lab allows to overcome the limitations of facilities and infrastructure contained in the laboratory with computerized simulations of experiments to be carried out in the laboratory (Rasteiroet in Domingues, et al., 2010). Hamida, et al (2013) suggested that to carry out the practicum not only conduct experiments in the laboratory, students can also do it in virtual labs. In the opinion of Putra in Karlinda (2013): Virtual laboratory is one of the learning content that is tangible computer software designed so that one can carry out experimental activities as they do experiments in a real laboratory. The use of school laboratory facilities is an interesting 
thing to discuss, considering practicum activities are believed to be one method that can be used to improve students' understanding and skills in studying chemistry. In addition, to prepare skilled students, able to think analytically in decision-making rather than mechanistic (routine) thinking and able to work and collaborate in solving problems, demanding learning processes that are held interactively, inspiring, fun, motivating students to actively participate, and provide sufficient space for initiative, creativity, and independence in accordance with the talents, interests, and physical and psychological development of students. This further emphasizes that learning is not only aimed at the achievement of cognitive aspects but also psychomotor and affective aspects in a balanced manner. When students learn chemistry, they are required not only to understand theoretically, but also empirically through practicum procedures so that students' cognitive abilities are also supported by good psychomotor and affective abilities. The results showed that many students thought that chemistry did not have any role or application in everyday life so it was not interesting to learn (Stieff and Wilensky, 2003). Laboratory plays an important role in effective chemical learning. These lab activities often encounter obstacles such as time problems and limited facilities owned by schools such as the availability of tools, materials, and even the unavailability of laboratories in schools. These obstacles cause practicum activities are not going well, even practicum activities are not done at all so that the teacher replaces practicum activities into classroom learning activities as usual without practicum which makes chemistry lessons a boring lesson so students do not master the lesson well and maximally. to overcome this problem is by doing a virtual practicum using a virtual lab. Hamida, et al (2013) stated that to carry out the practicum not only do experiments in the laboratory, students can also do it in a virtual lab. Virtual laboratories or commonly referred to as Virtual Lab are a series of tools, materials, and laboratories in the form of computer software, which are operated by computers and can simulate activities in the laboratory as if the user were in the real laboratory (Kusumaningsih, et al., 2014) . Carnevale (2003) argues that virtual practicum-based learning can provide flexibility to time and place in doing so and other obstacles such as the unavailability of laboratories in schools can be overcome by virtual practicum activities. Virtual lab tents cannot be used to replace practicum activities in the actual laboratory, because practicum activities in a virtual lab cannot train students' process abilities that will only be obtained from practical work in the actual laboratory, but this virtual lab can be used as a learning media that can help students in understand the material that will be studied (Nurrokhmah and Sunarto, 2013). Through preliminary observations, there are still many obstacles in the implementation of practicum in schools. It was stated that "chemical practicum activities are also faced with various problems, including expensive laboratory equipment, limited laboratory facilities, and difficulties in practicing practicums on chemical concepts, especially abstract hydrocarbon materials. In the abstract chemical concept, there is a difficulty in displaying chemical processes directly through real laboratory activities which causes low levels of mastery of chemical concepts and creative thinking skills. Based on the description above, it is necessary to conduct a Practical Guidance Analysis study on Hydrocarbon learning with the research title "Analysis of Practicum Guidelines for Interacting Virtual Lab Models on Hydrocarbon Materials". The purpose of this study in general is:

1. How is the validity of virtual lab learning media in hydrocarbon labs from the results of the development carried out? 
2. What is the response of the teacher and students to the virtual lab in practice the decline of hydrocarbons from the results of the development carried out?

3. What is the virtual lab implementation in the hydrocarbon lab from the results of the development carried out?

\section{Methodology of The Research}

The method used in this research is the Research and Development ( $R \& D$ ) method. Research and Development ( $R \& D$ ) is a research method used to produce certain products, and test the effectiveness of these products (Sugiyono, 2011). Steps to use the Research and Development (R \& D) method are: 1). Potential and Problems. 2). Data collection. 3). Product Design. 4). Design Validation. 5). Design Improvement. 6). Product Trial. 7). Product Revision. 8). Test Use. 9) Product Revision. 10) Mass Production. The steps of the research carried out in this study only reached stage 7 , namely limited product revision due to the limited time and expertise of researchers to carry out the next steps. The study was conducted in Deli Serdang District, North Sumatra. The selection of cities that are used as research locations is limited, through consideration of locations that are easily accessible to the author. The population in this study were all XI grade science specialization students in Medan. Due to the limitations of the researcher, the sample was chosen randomly purposively. Samples are selected from high schools that have laboratories with inadequate facilities. The school that was sampled in this study was the Pure Smart Private High School Percut Sei Tuan. The distribution of student distribution at the schools used as samples is illustrated in Table 1 below.

Table 1. Description of the population and sample in the high school set as a sample in the study Practical guide analysis using a Virtual Laboratory

\begin{tabular}{|c|c|c|c|c|c|}
\hline No & $\begin{array}{c}\text { High school } \\
\text { name }\end{array}$ & Total Students & $\begin{array}{c}\text { Total Class } \\
\text { Parallel }\end{array}$ & Class Sample & Total Sampel \\
\hline 1. & $\begin{array}{c}\text { SMA Cerdas } \\
\text { Murni }\end{array}$ & 210 & 3 & 2 class & 72 class \\
\hline
\end{tabular}

Sampling was done using purposive sampling technique. The sample in the study were students of class XI MIA 2 as an experimental group with learning using virtual laboratories and students of class XI MIA 1 as a control group using conventional learning. The sample in each group amounted to 36 people. Data retrieval is done using a description of students' concept understanding. The number of samples taken from each class is 36 people. This type of research is experimental research. Experimental research is research that is used to see the effect of specific treatment on the variables studied and under controlled conditions. Therefore, in the experimental study there were experimental classes and control classes.

\section{Results and Discussion}

\subsection{Results}

To determine the effect of the use of virtual laboratories on mastery of concepts and students' creative thinking skills, it was conducted by distributing evaluation questions consisting of initial test questions and final test questions both in the control class and 
experimental class. Based on the results of the initial tests and the final tests that have been given, it can be concluded that there is an influence from the use of virtual laboratories, which can be seen from the increase in the N-Gain value both in the control class and experimental class and can also be seen from the results of the t-test itself. Hypothesis testing is done to find out whether there is a difference in mastery of concepts and creative thinking abilities after being given treatment between the initial test and the final test for the experimental class and without being given treatment between the initial test and the final test for the control class. virtual lab developed. In the second aspect as many as $90.05 \%$ of students felt a new atmosphere in the classroom and the novelty of learning with a virtual lab, the way the teacher taught and how the teacher responded to the comments / responses / questions of students. As many as $85.50 \%$ of students were interested in the implementation of learning by expressing their interest in following the learning with the development virtual lab. In the fourth aspect as many as $93.94 \%$ of students are interested and better understand the material by using the virtual lab of the development results. In the fifth aspect, $90.06 \%$ of students are interested and understand the guidelines for using virtual labs. Based on limited trials for teachers and students, the assessment of compliance by observers and students' responses after using the virtual lab results from the development of the results can be categorized into very high categories, namely the average results of the teacher's response to the content suitability aspect of $95.24 \%$ in very high categories and the ease of use aspect of $94.72 \%$ is very high, the average student response to ease of use aspect is $94.85 \%$ in very high category, and the average observer's assessment of virtual lab implementation is $87.18 \%$ in the high category and The results of the students 'response questionnaire which stated that the students' positive response was $85.50 \%$ in the very high category, it can be concluded that the virtual lab in the freezing point lab and the osmotic pressure of the solution being developed is valid and feasible to use.

The sample in each group amounted to 36 people. Data retrieval is done using a description of students' concept understanding. Data analysis using independent sample TTest test obtained $\mathrm{t}$ count of 3.021 with $\mathrm{t}$ table 2.045 means that $\mathrm{t}$ count $>\mathrm{t}$ table and significant value $0.004<0.05$. Then Ho is rejected and $\mathrm{H} 1$ is accepted at a significant level of 0.05 so it is concluded that there is a significant difference between the average posttest value of the experimental group and the control group. This shows that there is an effect of applying virtual laboratories to students' concept understanding.

\subsection{Discussion}

In this research development produced a virtual lab product in a hydrocarbon practicum. The development of this virtual lab product was carried out based on the results of preliminary studies conducted in several high schools / MAs in Medan City and Deli Serdang District stating that teachers and students were still rarely practicing in schools. This statement was obtained from the results of interviews and questionnaires analysis of the needs of teachers and students. The results of interviews and questionnaires stated that practicum activities on hydrocarbon materials were not carried out because they did not support school facilities and infrastructure such as the unavailability of tools and practicum materials to be used. The virtual lab product from the development of this research is expected to help students to do practicum more easily and attract students' interest in participating in hydrocarbon learning. To find out the validity or the absence of a virtual lab as a result of this 
development, a validity test was conducted which was assessed by expert validation, the trial was limited to teachers and students, and also the use of virtual labs in the learning process.

Validity test carried out by expert validation includes aspects of compliance with the curriculum, construct aspects, and aspects of ease of use. The limited trial phase for teachers includes aspects of content suitability with curriculum and ease of use aspects, while for students only the trial is limited to the ease of use of the virtual lab developed. The implementation of virtual labs in the learning process was assessed by 3 observers. The implementation of limited trials and virtual lab implementation resulting from the development was carried out in the Pure Smart Private High School Percut Sei Tuan in Deli Serdang Regency. The results obtained from the validity test by expert validation stated that the virtual lab of the development results was valid. This was obtained based on the results of the validity test which obtained a very high category on the aspect of suitability of content with the curriculum, aspects of the construct, and aspects of ease of use of the virtual lab of the development results. In the results of limited trials conducted by the teacher on aspects of content compatibility with curriculums and aspects of ease of use of virtual labs the results of development have a very high category. The very high category is also obtained from the results of student responses to the ease of use of the virtual lab developed so that it can be concluded that the development of virtual labs is feasible to use. declared valid and feasible to use.

\section{Conclusion}

Based on the results of data analysis and discussion, it can be concluded that: Virtual labs in the developed Hydrocarbon practicum are declared valid and suitable for use in school learning. This can be seen from the average percentage score on aspects of content compatibility with the curriculum, construction aspects and ease of use aspects are very high categories. The results of the teacher's response to the aspect of suitability of content with the curriculum, and aspects of ease of use have very high categories as well as student responses to aspects of ease of use also have a very high category. The virtual lab implementation in the Hydrocarbon practicum of the development results is declared good because the assessment results get a high category of 1 observer and a very high category of 2 observers and the results of student responses after using the virtual lab the results of the development in very high category learning.

\section{References}

Anonim. 2016. Pengembangan Media Pembelajaran Pada Dunia Pendidikan. [online]. http://mas-boy69.blogspot.co.id/. Diakses pukul 20.05 pm tanggal 20 Januari 2016. Arsyad, A. 2013. Media Pembelajaran. PT Raja Grafindo Persada. Jakarta. Carnevale, D. 2003. The Virtual Lab Experiment. The Chronicle of Higher Education. Dalgarno, B., A. G. Bishop, W. Aadlong, dan D. R. Bedgood Jr. 2009. Effectiveness Of a Virtual Laboratory as a Preparatory Resource For Distance Education Chemistry Students. Computers \& Education An International Journal.

Herga, N. R., Cagran, B., dan Dinevski, D. 2016. Virtual Laboratory in the Role of Dynamic Visualisation for Better Understanding of Chemistry in Primary School. International Journal 
of Mathematics, Science \& Technology Education.

Jaya, H. 2011. PengembanganLaboratorium Virtual untuk Kegiatan Praktikum dan

Memfasilitasi Pendidikan Karakter di SMK. Jurnal Pendidikan Vokasi.

Parno, D dan D. P. Ninditya. 2008. Desain dan Implementasi Laboratorium Maya (V-Lab) Aplikasi Modul Lensa Optik untuk Membantu Pelaksanaan Praktikum Fisika. Jurnal Informatika Komputer.

Pujiati, A. dan Nurhayati. 2012. Pengaruh Model Pembelajaran (Berbantuan Laboratorium Virtual) dan Minat Belajar Tehadap Kemampuan Berpikir Kreatif Kimia. Jurnal Universitas Indraprasta PGRI. Jakarta .

Sugiyono. 2011. Metode Penelitian Pendidikan : pendekatan Kuantitatif, Kualitatif, dan R\&D. Alfabeta. Bandung.

Tim Penyusun. 2006. Panduan Penyusunan Kurikulum Tingkat Satuan Pendidikan Jenjang Pendidikan Dasar Dan Menengah. Badan Standar nasional Pendidikan. Jakarta.

Tim Penyusun. 2014. Permen Nomor 59 tentang Kurikulum SMA, Karakteristik Mata Pelajaran Kimia Lampiran III 10d tentang Mapel Peminatan Kimia. Kementrian Pendidikan dan Kebudayaan RI. Jakarta.

Tim Pascasarjana UNIMED, (2010), Pedoman Administrasi dan Penulisan Tesis \& Disertasi. Medan: Program Pascasarjana UNIMED 